UDC 616.12-008.331.1-06:616.44-008.64]-085.224-036.8
DOI: $10.15587 / 2519-4798.2020 .209166$

\title{
EFFICIENCY OF DOUBLE FIXED COMBINED THERAPY IN PATIENTS WITH ARTERIAL HYPERTENSION AND ASSOCIATED THYROTOXICOSIS AFTER ONE YEAR OF TREATMENT
}

\author{
V. Tseluyko, D. Korchagina
}

\begin{abstract}
Мета дослідження: очінити ефективність різних фіксованих подвійних комбінацій антигіпертензивних препаратів за результатами амбулаторного моніторування артеріального тиску проаналізувати їх вплив на ичентральний артеріальний тиск та ремоделювання серия у хворих на артеріальну гіпертензію та тиреотоксикоз.
\end{abstract}

Матеріали і методи. До дослідження увійшло 50 хворих.Включені у дослідження хворі на АГ та компенсований TT $(n=25)$ методом сліпих конвертів були рандомізовані на групи терапії фіксованими комбінаціями периндоприл+індапамід у добовій дозі 5/1,25 мг вранці натче або периндоприл+амлодипін у добовій дозі 5/5 мг враниі натче. Хворим на АГ та некомпенсований ТТ призначали фіксовану комбінаиію бісопрололу з периндоприлом у добовій дозі 5/5 мг вранияі натче. Групи були статистично порівняні за віком, тривалістю ЗГТ, тривалістю АГ, рівнем офісного САТ, ДАТ при включенні у дослідження. Кожен пацієнт був обстежений та консультований ендокринологом та кардіологом. Спостереження за хворими тривало 12 місяців, через рік дослідження проведено АМАТ та ЕхоКГ з метою вивчення ефективності АГТ у хворих на АГ та ТT.

Результати та їх обговорення. Через 6 міс. лікування 8 (16\%) хворих були виключенні з дослідження, з яких 6 (75\%) у зв'язку з відсутністю досягнення еутиреозу та потребою у хірургічному лікуванні ТT, $2(25 \%$ в зв'язку з необхідністю призначення іншої антиаритмічної терапії, ніж бісопролол. Вивчені фіксовані комбінації антигіпертензивних препаратів, а саме периндоприла з індапамідом, периндоприла з амлодипіном та бісопрололу з периндоприлом забезпечують зниження артеріального тиску у хворих на артеріальну гіпертензію з супутнім тиреотоксикозом за результатами АМАТ.

Висновки. Фіксована комбінація периндоприла з індапамідом, периндоприла з амлодипіном та бісопрололу з периндоприлом забезпечували як зниження АТ за показниками АМАТ, так $і$ изентрального артеріального тиску. Проте достовірного поліпшення структурно-функиіонального станусерия не встановлено

Ключові слова: ремоделювання серия, тиреотоксикоз, артеріальна гіпертензія, фіксована комбінована антигіпертензивна терапія, амбулаторне моні торування артеріального тиску

Copyright (C) 2020, V. Tseluyko, D. Korchagina.

This is an open access article under the CC BY license (http://creativecommons.org/licenses/by/4.0).

\section{Introduction}

Study of the features of arterial hypertension (AH) on the background of thyroid dysfunction (TD) showed that $\mathrm{AH}$ is more closely associated with hyperthyroidism than with hypothyroidism [1]. Yildiz C. and et al. (2019) found in patients with thyrotoxicosis (TT) a significant increase in systolic blood pressure (SBP), heart rate (HR) and central SBP, which is an independent risk factor for cardiovascular complications, which is more accurate than the level of peripheral blood pressure (BP) displays after loading of the left ventricle (LV) and closely correlates with the left ventricular myocardial mass index (LVMMI) n patients with $\mathrm{AH}[2,3]$. In patients with TT, the connection of arterial stiffness with the level of thyroid hormones has been proven [2, 4].

Thyrotoxicosis, like AH, is considered a modified risk factor for cardiovascular complications due to the possibility of thyrostatic therapy or surgical treatment of the causes of TT. The reversibility of structural and functional changes in the heart in the comorbid course of $\mathrm{AH}$ and TT, which is characterized by damage to target or- gans with the development and progression of early severe cardiovascular disorders, is estimated ambiguously.

According to the results of a professional study of the restoration of clinical, instrumental indicators of the cardiovascular system in patients with diffuse toxic goiter after elimination of thyrotoxicosis, neither in conservative therapy nor in the use of surgical treatment of reversibility of symptoms in most patients was not observed [5].

Structural changes in the aorta, which cause its rigidity, are degenerative and irreversible, but a number of studies have shown the possibility of a positive effect of therapy on arterial stiffness under the influence of antihypertensive drugs (AHD) [6]. The free combinations of AHD patients with AH with concomitant TT proposed in a few studies do not meet modern requirements for the strategy of "one tablet" in AHT [7].

The aim of the study: to evaluate the effectiveness of double fixed combinations of antihypertensive drugs perindopril + indapamide, perindopril + amlodipine, bisoprolol + perindopril by the results of outpatient blood pressure monitoring and to analyze the effect of combinations on central 
blood pressure and hypertension of the heart in patients associated with thyrotoxicosis after a year of therapy.

\section{Materials and methods}

Of the 75 patients with AH with TT, who consistently went to the clinic or were hospitalized in the clinic of the State Institution "Institute of Endocrine Pathology named after V. Ya. Danilevsky of National Academy of Medical Sciences of Ukraine", for the period from November 2017 to June 2019, the study included 50 who met the inclusion criteria: age over 18 years; thyrostatic therapy for history of hyperthyroidism and/ or thyroid stimulating hormone $(\mathrm{TSH})<0.4 \mathrm{mIU} / 1$, double AHT and/or systolic BP (SBP) $>140 \mathrm{~mm} \mathrm{Hg}$ and/or the level of diastolic BP (DBP) $>90 \mathrm{~mm} \mathrm{Hg}$ when included in the study, no side effects when taking angiotensin-converting-enzyme inhibitors (ACE inhibitor), calcium channel blockers (CCB). Criteria for non-inclusion in the study were: diabetes mellitus; valvular heart disease, acute cerebrovascular accident or a history of myocardial infarction, glomerular filtration rate $<30$ $\mathrm{ml} / \mathrm{min} / 1.73 \mathrm{~m}^{2}$, bronchial asthma.

Each patient was examined and consulted by an endocrinologist and cardiologist. AH was determined according to the recommendations of the European Society of Cardiology (ESH/ESC 2018) [8]. The diagnosis of TT was established in accordance with the guidelines of the American Thyroid Association (ATA) for the management of patients with hyperthyroidism and other causes of thyrotoxicosis (2016) [9]. According to the Declaration of Helsinki, all patients were informed about the goals and methods of this clinical trial, and they all agreed to participate. Minutes of the meeting of the Department of Cardiology and Functional Diagnostics of the Kharkiv Medical Academy of Postgraduate Education No. 10, dated 16.11.2017.

When included in the study, the average values of the levels of office SBP and DBP, in patients included in the study, were $151.85 \pm 9.35 \mathrm{~mm} \mathrm{Hg}$, respectively. and $82.25 \pm 8.11 \mathrm{~mm} \mathrm{Hg}$, which was assessed as unsatisfactory control of BP. Included in the study patients with $\mathrm{AH}$ and compensated TT $(n=25)$ by blind envelope were randomized to treatment groups with double fixed combinations of perindopril + indapamide in a daily dose of $5 / 1.25 \mathrm{mg}$ in the morning on an empty stomach or perindopril + amlodipine in a daily dose of $5 / 5 \mathrm{mg}$ in the morning on an empty stomach. Patients with $\mathrm{AH}$ and uncompensated TT were prescribed a fixed combination of bisoprolol with perindopril in a daily dose of $5 / 5$ $\mathrm{mg}$ in the morning on an empty stomach. The groups were statistically compared by age, HRT duration, AH duration, office SBP level, DBP when included in the study. Clinical and anamnestic characteristics of patients are given in Table 1.

Table 1

Clinical and anamnestic characteristics of the examined groups of patients with arterial hypertension and thyrotoxicosis

\begin{tabular}{|c|c|c|c|c|c|}
\hline \multicolumn{2}{|c|}{ Indicator } & $\begin{array}{c}\text { Group } 1 \\
\text { ACE inhibitor+D, } \\
(\mathrm{n}=12)\end{array}$ & $\begin{array}{c}\text { Group } 2 \\
\text { ACE inhibitor+CCB, } \\
(\mathrm{n}=13)\end{array}$ & $\begin{array}{c}\text { Group } 3 \\
\beta-B+A C E \text { inhibitor, } \\
\quad(n=25)\end{array}$ & $\mathrm{p}$ \\
\hline \multicolumn{2}{|c|}{1} & 2 & 3 & 4 & 5 \\
\hline \multicolumn{2}{|c|}{ Duration of TT, years } & $4.0 \pm 2.8$ & $4.3 \pm 1.4$ & $3.6 \pm 3.2$ & $\begin{array}{l}\mathrm{p}_{1-2}=0.8 \\
\mathrm{p}_{1-3}=0.7 \\
\mathrm{p}_{2-3}=0.5\end{array}$ \\
\hline \multicolumn{2}{|c|}{ Duration of $\mathrm{AH}$, years } & $6.2 \pm 3.2$ & $6.7 \pm 2.7$ & $6.0 \pm 4.9$ & $\begin{array}{l}\mathrm{p}_{1-2}=0.7 \\
\mathrm{p}_{1-3}=0.9 \\
\mathrm{p}_{2-3}=0.6\end{array}$ \\
\hline \multicolumn{2}{|c|}{ Age, years } & $46.2 \pm 8.9$ & $51.4 \pm 14.3$ & $51.8 \pm 14.4$ & $\begin{array}{l}\mathrm{p}_{1-2}=0.3 \\
\mathrm{p}_{1-3}=0.2 \\
\mathrm{p}_{2-3}=0.9\end{array}$ \\
\hline \multicolumn{2}{|c|}{ Women, n (\%) } & $12(100 \%)$ & $12(92.3 \%)$ & $23(92 \%)$ & \multirow{2}{*}{$\begin{array}{l}\mathrm{p}_{1-2}=0.5 \\
\mathrm{p}_{1-3}=0.5 \\
\mathrm{p}_{2-3}=0.7\end{array}$} \\
\hline \multicolumn{2}{|c|}{ Men, n (\%) } & - & $1(7.7 \%)$ & $2(8 \%)$ & \\
\hline \multirow{4}{*}{$\begin{array}{c}\text { Office SBP } \\
\text { level, } \mathrm{mm} \mathrm{Hg}\end{array}$} & $\begin{array}{c}\text { when included in } \\
\text { the study }\end{array}$ & $148.65 \pm 15.12$ & $146.7 \pm 12.6$ & $150.23 \pm 15.5$ & $\begin{array}{l}\mathrm{p}_{1-2}=0.7 \\
\mathrm{p}_{1-3}=0.8 \\
\mathrm{p}_{2-3}=0.5\end{array}$ \\
\hline & After 1 month & $134.5 \pm 6.75$ & $133.4 \pm 5.2$ & $135.24 \pm 5.12$ & $\begin{array}{l}\mathrm{p}_{1-2}=0.7 \\
\mathrm{p}_{1-3}=0.7 \\
\mathrm{p}_{2-3}=0.3\end{array}$ \\
\hline & After 3 months & $132.3 \pm 5.18$ & $133.57 \pm 4.1$ & $134.43 \pm 5.3$ & $\begin{array}{l}\mathrm{p}_{1-2}=0.5 \\
\mathrm{p}_{1-3}=0.2 \\
\mathrm{p}_{2-3}=0.6\end{array}$ \\
\hline & After 12 months & $133.1 \pm 4.4$ & $132.5 \pm 5.23$ & $133.23 \pm 4.2$ & $\begin{array}{l}\mathrm{p}_{1-2}=0.8 \\
\mathrm{p}_{1-3}=0.9 \\
\mathrm{p}_{2-3}=0.6\end{array}$ \\
\hline
\end{tabular}


Continuation of Table 1

\begin{tabular}{|c|c|c|c|c|c|}
\hline \multicolumn{2}{|c|}{1} & 2 & 3 & 4 & 5 \\
\hline \multirow{4}{*}{$\begin{array}{l}\text { Office DBP } \\
\text { level, mm Hg }\end{array}$} & $\begin{array}{l}\text { when included in } \\
\text { the study }\end{array}$ & $84.4 \pm 7.3$ & $85.3 \pm 6.6$ & $80.5 \pm 4.2$ & $\begin{array}{l}\mathrm{p}_{1-2}=0.7 \\
\mathrm{p}_{1-3}=0.0 \\
\mathrm{p}_{2-3}=0.0\end{array}$ \\
\hline & After 1 month & $83.7 \pm 6.4$ & $84.3 \pm 5.7$ & $82.4 \pm 4.8$ & $\begin{array}{l}\mathrm{p}_{1-2}=0.8 \\
\mathrm{p}_{1-3}=0.5 \\
\mathrm{p}_{2-3}=0.3\end{array}$ \\
\hline & After 3 months & $84.7 \pm 5.5$ & $83.5 \pm 4.4$ & $83.6 \pm 3.7$ & $\begin{array}{l}\mathrm{p}_{1-2}=0.6 \\
\mathrm{p}_{1-3}=0.5 \\
\mathrm{p}_{2-3}=0.9\end{array}$ \\
\hline & After 12 months & $85.2 \pm 4.7$ & $83.4 \pm 5.1$ & $83.2 \pm 4.1$ & $\begin{array}{l}\mathrm{p}_{1-2}=0.4 \\
\mathrm{p}_{1-3}=0.2 \\
\mathrm{p}_{2-3}=0.9\end{array}$ \\
\hline \multicolumn{2}{|c|}{ BMI, $\mathrm{kg} / \mathrm{m}^{2}$} & $24.4 \pm 2.8$ & $24.0 \pm 3.0$ & $23.7 \pm 3.8$ & $\begin{array}{l}\mathrm{p}_{1-2}=0.8 \\
\mathrm{p}_{1-3}=0.6 \\
\mathrm{p}_{2-3}=0.8\end{array}$ \\
\hline \multicolumn{2}{|c|}{$\begin{array}{l}\text { TSH level at inclusion in the study, } \\
\text { mME } 1\end{array}$} & $0.91 \pm 0.38$ & $1.19 \pm 0.77$ & $0.06 \pm 0.06$ & $\begin{array}{l}\mathrm{p}_{1-2}=0.3 \\
\mathrm{p}_{1-3}=0.0 \\
\mathrm{p}_{2-3}=0.0\end{array}$ \\
\hline \multicolumn{2}{|c|}{ TSH level after 12 months, mIU/ } & $1.1 \pm 0.6$ & $1.0 \pm 0.4$ & $0.9 \pm 0.3$ & $\begin{array}{l}\mathrm{p}_{1-2}=0.9 \\
\mathrm{p}_{1-3}=0.3 \\
\mathrm{p}_{2-3}=0.3\end{array}$ \\
\hline
\end{tabular}

Patients who did not reach the target BP level for ABPM after 1 month underwent AHT adjustment with increasing perindopril dose to full therapeutic and repeated ABPM after 1 month, provided that BP monitoring was satisfactory based on home monitoring. If the target level of SBP was not reached in the future according to ABPM, the dose of the second drug in combination was increased to full therapeutic.

Control ABPM and echocardiography were performed after one year of therapy.

The complex of examination of patients in addition to general - clinical and anthropometric methods included measurements of office BP and ABPM, which were carried out according to the European recommendations on $\mathrm{AH}[8]$.

Body mass index (BMI) was determined by the formula: $\mathrm{BMI}=$ body weight $/(\text { height })^{2}, \mathrm{~kg} / \mathrm{m}^{2}$. Office BP was measured three times with an interval of two minutes and the arithmetic mean for SBP and DBP was calculated. Outpatient BP monitoring (ABPM) was performed on an AVRM 04 device (Meditech, Hungary). Measurements were performed every 15 minutes during the day and every 30 minutes at night (from 22.00 to 6.00 ). Data processing was performed using the software of the device on a personal computer with the analysis of the following indicators: average daily values of SBP, DBP and average values of SBP and DBP during the day, night. According to the recommendations of the European Society of Cardiology (ESH/ESC 2018), the diagnostic threshold for $\mathrm{AH}$ was considered to be $\geq 130 / 80 \mathrm{~mm} \mathrm{Hg}$. for 24 hours, $\geq 135 / 85 \mathrm{~mm} \mathrm{Hg}$ for the average daily value and $\geq 120 / 70 \mathrm{~mm} \mathrm{Hg}$ for the average night value [8].
Echocardiographic (EchoCG) studies were performed on the device "UltimaPA" SS (Ukraine) according to the standards of the American Echo-CG Association, using a sensor with an ultrasound frequency of 3.5 $\mathrm{MHz}[10]$. The structural parameters of the heart were evaluated: anterior-posterior size of the left atrium (LA, cm), final systolic size (FSS, cm), final diastolic size (FDS, cm), the thickness of the posterior wall of the LV in diastole (TPWLVd, $\mathrm{cm}$ ), the thickness of the interventricular septum in diastole (TIVSd, cm), final systolic volume $(\mathrm{FSV}, \mathrm{ml})$ and final diastolic volume $(\mathrm{FDV}, \mathrm{ml}) \mathrm{LV}$, ejection fraction according to Teicholz (EF, \%), myocardial mass of LV (MMLV). Diastolic function of LV was investigated using the results of measurements of transmitral blood flow, which include the rates of peak early filling (wave E) and late diastolic filling in atrial systole (wave A), the calculation of the ratio of velocities E/A [10]. According to echocardiographic recommendations for a more objective assessment of the size of the left atrium and myocardial mass, the indicators were indexed to body surface area in obese patients $\left(\mathrm{BMI}<30 \mathrm{~kg} / \mathrm{m}^{2}\right)$ and in obese patients $\left(\mathrm{BMI} \geq 30 \mathrm{~kg} / \mathrm{m}^{2}\right)$, for growth in the degree of 2.7 [10]. In the course of the work, the delta of indicators was evaluated - the difference between the initial indicators and those obtained after 12 months of treatment was calculated.

Statistical processing of the obtained data was performed using the software package Statistica 13.0. In the normal distribution, quantitative traits were presented as mean \pm standard deviation $(\mathrm{M} \pm \sigma)$. The reliability of the results was assessed by Student's t-test for dependent and independent samples. In the case of a different distribution of data, they were presented in the form of median 
and interquartile range $(\mathrm{Me}(25 ; 75)$ and used the Mann-Whitney test. Differences in the studied traits were considered statistically significant when the probability of validity of the null hypothesis is less than $5 \%$ $(p<0.05)$. Estimation of the significance of frequency differences was calculated using the Pearson test. When performing a correlation analysis for independent variants, the correlation between the two variants at a value $<0.05$ was considered statistically significant.

\section{Results}

There was no need to discontinue AHT due to the occurrence of AHD side effects throughout the follow-up period. After 1 month of monitoring the level of office SBP control was considered satisfactory (Table 1). It should be noted that the frequency of reaching the target office BP significant difference between the groups is not established. After 6 months of treatment, 8 (16\%) patients were excluded from the study, of which $6(75 \%)$ due to lack of euthyroidism and the need for surgical treatment of TT, $2(25 \%)$ due to the need for other antiarrhythmic therapy than bisoprolol. Of the $8(16 \%)$ patients excluded from the study, 4 ( $8 \%$ ) patients were in a state of thyroid compensation at the beginning of the observation, but during the observation a recurrence of TT and $4(8 \%)$ in a state of TT decompensation were established.

Analysis of the ABPM results obtained after one year of therapy revealed that the target level of BP (according to $24 \mathrm{SBP})$ was reached in 39 (92.8\%). Indicators that characterize the daily SBP profile (24 SBP, aSBPday, aSBPnight) after 12 months of treatment in both groups AHT were significantly lower than when included in the study $(\mathrm{p}<0,05)$, which indicates the effectiveness of combinations of AHD (Table 2).

Table 2

Dynamics of indicators $(\Delta)$ of outpatient monitoring of blood pressure and central SBP in patients with AH with concomitant thyrotoxicosis depending on the fixed combinations of AHD used when included in the study and after

12 months of treatment

\begin{tabular}{|c|c|c|c|c|}
\hline Indicator & $\begin{array}{c}\text { Group } 1 \\
\text { ACE inhibitor+D, } \\
(\mathrm{n}=10)\end{array}$ & $\begin{array}{c}\text { Group } 2 \\
\text { ACE inhibitor+CCB, } \\
(\mathrm{n}=11)\end{array}$ & $\begin{array}{c}\text { Group } 3 \\
\beta-\mathrm{B}+\mathrm{ACE} \text { inhibitor, } \\
\quad(\mathrm{n}=21)\end{array}$ & $\mathrm{p}$ \\
\hline $24 \mathrm{SBP}, \mathrm{mm} \mathrm{Hg}$ & $\begin{array}{c}134.7 \pm 4.6 \\
127.8 \pm 2.2 * \\
6.9 \pm 2.4\end{array}$ & $\begin{array}{c}134.9 \pm 5.5 \\
127.6 \pm 4.4^{*} \\
7.3 \pm 1.1\end{array}$ & $\begin{array}{c}142.0 \pm 3.6 \\
128.4 \pm 2.5^{*} \\
13.6 \pm 1.1\end{array}$ & $\begin{array}{l}\mathrm{p}_{1-2}=0.6 \\
\mathrm{p}_{1-3}=0.0 \\
\mathrm{p}_{2-3}=0.0\end{array}$ \\
\hline 24 DBP, mm Hg. & $\begin{array}{c}78.0 \pm 3.5 \\
75.6 \pm 2.3 \\
2.4 \pm 1.2\end{array}$ & $\begin{array}{c}78.8 \pm 3.2 \\
76.5 \pm 3.1 \\
2.3 \pm 0.1\end{array}$ & $\begin{array}{c}77.9 \pm 2.8 \\
75.3 \pm 2.3 \\
2.6 \pm 0.5\end{array}$ & $\begin{array}{l}\mathrm{p}_{1-2}=0.7 \\
\mathrm{p}_{1-3}=0.5 \\
\mathrm{p}_{2-3}=0.0\end{array}$ \\
\hline $\begin{array}{l}\text { aSBPday, } \\
\mathrm{mm} \mathrm{Hg}\end{array}$ & $\begin{array}{c}137.9 \pm 4.4 \\
132.9 \pm 2.2^{*} \\
5.0 \pm 2.2 \\
\end{array}$ & $\begin{array}{c}138.9 \pm 5.5 \\
133.9 \pm 2.0^{*} \\
5.0 \pm 3.5\end{array}$ & $\begin{array}{c}144.0 \pm 3.8 \\
134.0 \pm 2.8^{*} \\
10.0 \pm 1.0 \\
\end{array}$ & $\begin{array}{l}\mathrm{p}_{1-2}=0.9 \\
\mathrm{p}_{1-3}=0.0 \\
\mathrm{p}_{2-3}=0.0\end{array}$ \\
\hline $\begin{array}{l}\text { aDBPday, } \\
\text { mm Hg }\end{array}$ & $\begin{array}{c}81.0 \pm 3.4 \\
79.2 \pm 3.3 \\
1.8 \pm 0.1\end{array}$ & $\begin{array}{c}81.8 \pm 3.0 \\
80.2 \pm 3.0 \\
1.6\end{array}$ & $\begin{array}{c}81.0 \pm 3.4 \\
78.9 \pm 2.4 \\
2.1 \pm 1.0\end{array}$ & $\begin{array}{l}\mathrm{p}_{1-2}=0.0 \\
\mathrm{p}_{1-3}=0.3 \\
\mathrm{p}_{2-3}=0.1\end{array}$ \\
\hline $\begin{array}{l}\text { aSBPnight, } \\
\text { mm Hg }\end{array}$ & $\begin{array}{c}128.5 \pm 6.2 \\
122.4 \pm 3.4^{*} \\
6.1 \pm 2.8 \\
\end{array}$ & $\begin{array}{c}129.13 \pm 5.6 \\
119.33 \pm 4.6 \\
9.8 \pm 1.0\end{array}$ & $\begin{array}{c}133.7 \pm 3.7 \\
119.8 \pm 2.9^{*} \\
13.9 \pm 0.8\end{array}$ & $\begin{array}{l}\mathrm{p}_{1-2}=0.0 \\
\mathrm{p}_{1-3}=0.0 \\
\mathrm{p}_{2-3}=0.0\end{array}$ \\
\hline $\begin{array}{l}\text { aDBPnight, } \\
\text { mm Hg }\end{array}$ & $\begin{array}{l}71.2 \pm 2.4 \\
69.5 \pm 2.1 \\
1.7 \pm 0.3 \\
\end{array}$ & $\begin{array}{c}73.5 \pm 3.9 \\
71.8 \pm 3.8 \\
1.7 \pm 0.1 \\
\end{array}$ & $\begin{array}{c}73.7 \pm 3.1 \\
70.2 \pm 2.6^{*} \\
3.5 \pm 0.5\end{array}$ & $\begin{array}{l}\mathrm{p}_{1-2}=0.3 \\
\mathrm{p}_{1-3}=0.0 \\
\mathrm{p}_{2-3}=0.0\end{array}$ \\
\hline HR max, beats/min & $\begin{array}{c}94.9 \pm 10.3 \\
99.2 \pm 11.4 \\
4.3 \pm 1.1\end{array}$ & $\begin{array}{c}95.3 \pm 12.0 \\
94.2 \pm 8.8 \\
1.1 \pm 3.2\end{array}$ & $\begin{array}{c}106.8 \pm 9.4 \\
98.2 \pm 9.3^{*} \\
8.6 \pm 0.1\end{array}$ & $\begin{array}{l}\mathrm{p}_{1-2}=0.0 \\
\mathrm{p}_{1-3}=0.0 \\
\mathrm{p}_{2-3}=0.0\end{array}$ \\
\hline HR min, beats/min & $\begin{array}{c}56.8 \pm 3.8 \\
55.1 \pm 3.1 \\
1.7 \pm 0.7\end{array}$ & $\begin{array}{c}59.2 \pm 5.6 \\
54.0 \pm 4.0 * \\
5.2 \pm 1.6\end{array}$ & $\begin{array}{c}64.1 \pm 6.5 \\
58.3 \pm 6.0^{*} \\
5.8 \pm 0.5\end{array}$ & $\begin{array}{l}\mathrm{p}_{1-2}=0.0 \\
\mathrm{p}_{1-3}=0.0 \\
\mathrm{p}_{2-3}=0.1\end{array}$ \\
\hline $24 \mathrm{HR}$, beats/min & $\begin{array}{c}75.8 \pm 7.6 \\
77.1 \pm 6.7 \\
1.3\end{array}$ & $\begin{array}{c}77.2 \pm 8.8 \\
74.0 \pm 6.4 \\
3.2 \pm 2.4\end{array}$ & $\begin{array}{c}85.45 \pm 7.9 \\
78.26 \pm 7.7 \\
7.2 \pm 0.2\end{array}$ & $\begin{array}{l}\mathrm{p}_{1-2}=0.0 \\
\mathrm{p}_{1-3}=0.0 \\
\mathrm{p}_{2-3}=0.0\end{array}$ \\
\hline $\mathrm{cSBP}$ & $\begin{array}{c}136.7 \pm 13.2 \\
121.0 \pm 5.2^{*} \\
15.7 \pm 8.0\end{array}$ & $\begin{array}{l}142.2 \pm 15.5 \\
123.6 \pm 5.1^{*} \\
18.6 \pm 10.4\end{array}$ & $\begin{array}{c}133.9 \pm 6.2 \\
118.6 \pm 4.2^{*} \\
15.3 \pm 2.0\end{array}$ & $\begin{array}{l}\mathrm{p}_{1-2}=0.5 \\
\mathrm{p}_{1-3}=0.8 \\
\mathrm{p}_{2-3}=0.2\end{array}$ \\
\hline AIX 75 & $\begin{array}{c}31.8 \pm 6.7 \\
28.6 \pm 6.4 \\
3.2 \pm 0.3\end{array}$ & $\begin{array}{c}32.7 \pm 5.8 \\
28.3 \pm 4.9 \\
4.4 \pm 0.9\end{array}$ & $\begin{array}{c}26.6 \pm 6.2 \\
24.0 \pm 3.5 \\
2.6 \pm 2.7\end{array}$ & $\begin{array}{l}\mathrm{p}_{1-2}=0.0 \\
\mathrm{p}_{1-3}=0.5 \\
\mathrm{p}_{2-3}=0.0\end{array}$ \\
\hline
\end{tabular}

Note: ${ }^{*}-\mathrm{p}<0.01$ - the reliability of the difference in the treatment process; \#-probable difference in performance during treatment; $\Delta$ - the difference compared to the results before treatment 
Given that LVMH is a powerful predictor of mortality, and effective treatment of $\mathrm{AH}$ involves the regression of LVMH in patients with $\mathrm{AH}$ according to echocardiography, we analyzed the dynamics of echocardiography after a year of therapy with various fixed combinations of AHT (Table 3). However, no significant differences between echocardiographic parameters at study entry and after one year of treatment were found in either group.

Table 3

Dynamics of echocardiography in patients with AH with concomitant thyrotoxicosis after a year of treatment and comparison between groups depending on the fixed combinations of used AHD $\left(\mathrm{p}_{\Delta}\right.$

\begin{tabular}{|c|c|c|c|}
\hline Indicator & $\begin{array}{c}\text { ACE } \\
\text { inhibitor+D } \\
(\mathrm{n}=10)\end{array}$ & $\begin{array}{c}\text { ACE inhibitor+ } \\
\text { CCB } \\
(\mathrm{n}=11)\end{array}$ & $\begin{array}{c}\text { ACE inhibitor+ } \\
\beta-B \\
(n=21)\end{array}$ \\
\hline \multirow{3}{*}{ FDS, cm } & $4.7 \pm 0.7$ & $4.6 \pm 0.5$ & $4.6 \pm 0.5$ \\
\hline & $4.6 \pm 0.6$ & $4.5 \pm 0.5$ & $4.6 \pm 0.4$ \\
\hline & $\Delta 0.1 \pm 0.1$ & $\Delta 0.1$ & \\
\hline \multirow{3}{*}{$\mathrm{FSS}, \mathrm{cm}$} & $3.2 \pm 0.6$ & $3.06 \pm 0.38$ & $3.2 \pm 0.4$ \\
\hline & $3.1 \pm 0.6$ & $3.06 \pm 0.38$ & $3.1 \pm 0.4$ \\
\hline & $\Delta 0.1$ & & $\Delta 0.1$ \\
\hline FDV, ml & $\begin{array}{c}101.5 \pm 32.7 \\
95.3 \pm 20.0 \\
\Delta 6.2 \pm 12.7\end{array}$ & $\begin{array}{l}96.3 \pm 22.9 \\
95.2 \pm 21.5 \\
\Delta 1.1 \pm 1.4\end{array}$ & $\begin{array}{l}97.6 \pm 20.2 \\
94.5 \pm 18.4 \\
\Delta 3.1 \pm 1.7 \\
\end{array}$ \\
\hline FSV, ml & $\begin{array}{l}43.9 \pm 21.7 \\
40.1 \pm 17.1 \\
\Delta 3.8 \pm 4.6\end{array}$ & $\begin{array}{c}38.8 \pm 10.1 \\
38.6 \pm 9.5 \\
\Delta 0.2 \pm 0.6\end{array}$ & $\begin{array}{l}40.5 \pm 13.0 \\
38.8 \pm 10.4 \\
\Delta 1.7 \pm 2.6\end{array}$ \\
\hline $\mathrm{SV}, \mathrm{ml}$ & $\begin{array}{c}57.6 \pm 14.1 \\
56.5 \pm 9.1 \\
\Delta 1.1 \pm 5.0\end{array}$ & $\begin{array}{l}59.0 \pm 16.8 \\
56.6 \pm 14.7 \\
\Delta 2.4 \pm 2.1\end{array}$ & $\begin{array}{c}57.7 \pm 14.8 \\
55.7 \pm 14.8 \\
\Delta 2.0\end{array}$ \\
\hline EF \% & $\begin{array}{c}61.9 \pm 8.9 \\
61.1 \pm 5.8 \\
\Delta 0.79 \pm 3.1\end{array}$ & $\begin{array}{c}61.4 \pm 8.9 \\
59.8 \pm 6.0 \\
\Delta 1.6 \pm 2.9\end{array}$ & $\begin{array}{c}60.1 \pm 8.2 \\
58.5 \pm 5.5 \\
\Delta 1.7 \pm 2.7\end{array}$ \\
\hline \multirow{3}{*}{$\begin{array}{l}\text { The thickness of } \\
\text { the interventric- } \\
\text { ular septum, cm }\end{array}$} & $1.0 \pm 0.1$ & $1.1 \pm 0.2$ & $1.1 \pm 0.1$ \\
\hline & $1.0 \pm 0.1$ & $1.0 \pm 0.2$ & $1.0 \pm 0.1$ \\
\hline & & $\Delta 0.1$ & $\Delta 0.1$ \\
\hline $\begin{array}{l}\text { The thickness of } \\
\text { the posterior LV } \\
\text { wall, } \mathrm{cm}\end{array}$ & $\begin{array}{l}1.0 \pm 0.09 \\
1.0 \pm 0.08\end{array}$ & $\begin{array}{l}1.0 \pm 0.18 \\
1.0 \pm 0.16\end{array}$ & $\begin{array}{l}1.0 \pm 0.14 \\
1.0 \pm 0.13\end{array}$ \\
\hline \multirow{3}{*}{$\mathrm{E} / \mathrm{A}$} & $1.2 \pm 0.3$ & $1.1 \pm 0.4$ & $1.1 \pm 0.33$ \\
\hline & $1.1 \pm 0.2$ & $1.1 \pm 0.3$ & $1.1 \pm 0.25$ \\
\hline & $\Delta 0.1 \pm 0.1$ & $\Delta 0.01 \pm 0.1$ & \\
\hline $\begin{array}{l}\text { LV myocardial } \\
\text { mass, } g\end{array}$ & $\begin{array}{l}175.2 \pm 56.5 \\
164.2 \pm 49.3 \\
\Delta 11.0 \pm 7.2\end{array}$ & $\begin{array}{c}175.6 \pm 57.0 \\
169.0 \pm 56.3 \\
\Delta 6.6 \pm 0.7\end{array}$ & $\begin{array}{l}181.9 \pm 47.0 \\
169.6 \pm 46.0 \\
\Delta 12.3 \pm 1.0\end{array}$ \\
\hline $\begin{array}{l}\text { LVMMI (by } \\
\text { body surface } \\
\text { area), } \mathrm{g} / \mathrm{m}^{2}\end{array}$ & $\begin{array}{c}105.0 \pm 31.1 \\
94.8 \pm 30.2 \\
\Delta 10.2 \pm 0.9\end{array}$ & $\begin{array}{c}96.7 \pm 30.1 \\
94.4 \pm 30.1 \\
\Delta 2.3\end{array}$ & $\begin{array}{c}106.3 \pm 22.6 \\
99.4 \pm 22.5 \\
\Delta 6.9 \pm 0.1\end{array}$ \\
\hline \multirow{3}{*}{$\begin{array}{l}\text { LVMMI } \\
\text { (by body sur- } \\
\text { face area), } \\
\mathrm{cm} / \mathrm{m}^{2}\end{array}$} & $1.9 \pm 0.2$ & $2.0 \pm 0.31$ & $2.3 \pm 0.3$ \\
\hline & $1.8 \pm 0.2$ & $2.0 \pm 0.30$ & $2.2 \pm 0.3$ \\
\hline & $\Delta 0.1$ & & $\Delta 0.1$ \\
\hline
\end{tabular}

\section{Discussion}

After one year of treatment, all studied double fixed combinations of AHD showed a statistically significant decrease in ABPM, but in the group of patients receiving a fixed combination of bisoprolol with perindopril showed a significant decrease in the indicators that characterize the daily profile of SBP (24 SBP, aSBPday, aSBPnight), as well as HR, i. e. the achievement of euthyroidism further contributed to the reduction of BP.

Although each of the proposed combinations of antihypertensive drugs in our study showed a positive effect on ABPM in patients with AH with TT, statistically significant dynamics of reduction in the size of the left atrial cavities, as well as the mass of LV and LVMMI were not detected. The data obtained in the study of the modern literature on the possibility of reversal of structural and functional changes in the heart after TT treatment, differ. Thus, according to the results of the dissertation study by I. L. Tsymbalyuk on the background of 6-month AHT was determined by a significant regression of LV hypertrophy [7], which does not coincide with the results of the study Alekseeva et al., which indicate an increase in left atrial dilatation - from $8.06 \%(5 / 62)$ to $25.8 \%(16 / 62)(\mathrm{p}<0.01)$, left ventricular hypertrophy from $14.5 \%(9 / 62)$ to $27.6 \%(17 / 62)(\mathrm{p}<0.01)$ and no tendency to decrease the size of the atrial and ventricular cavities, as well as wall thickness and myocardial mass after long-term drug treatment of TT [5].

The study of the effect of TT duration on heart remodeling performed in our study did not provide statistically significant confirmation of such a connection, which coincides with the results of Babenko's et al. observation on the possibility of developing stable LVMH and dilatation of LA in both long-term (5-10 years) and short-term (1-3 years) observation [11]. Perhaps more support is needed for the scientific evidence that an unfavorable prognostic factor for thyroid dysfunction is the duration of cumulative periods of abnormal TSH levels in both treated and untreated people $[12,13]$.

The American Thyroid Association for the Diagnosis and Treatment of Hyperthyroidism recommends a low level of evidence that after a standard course of thyrostatic therapy for 12-18 months, and in the absence of normalization of the thyroid condition may continue for another 12-18 months. It is obvious that in due time to reveal patients with negative dynamics in the sizes of cavities of heart during this time and to make the decision on prevention of prolongation at them of thyrostatic therapy the assessment of echocardiographic indicators allows. Moreover, the risk of recurrence after discontinuation of a full course of antithyroid therapy is $50-70 \%$ [14]. Along with the statement that most cardiac disorders in TT, including AH, return to normal when the euthyroid state is restored, it is the lack of restoration of myocardial structure and function can be considered as a cause of increased mortality from cardiovascular causes by 1.2 times and cerebrovascular complications 1.4 times in TT compared with the general population $[4,7]$.

Accordingly, in patients with comorbid $\mathrm{AH}$ with thyrotoxicosis, the choice of treatment should be based not only on laboratory criteria for maintaining euthyroid- 
ism, but also on data assessing the structural and functional state of the heart.

Study limitations. The study included a small cohort of patients with $\mathrm{AH}$ in combination with thyrotoxicosis, followed by studies of the largest cohort of patients. The study was dominated by women.

Prospects for further research. Long-term follow-up of this cohort of patients to address the impact of the duration of thyrotoxicosis on the course of $\mathrm{AH}$.

\section{Conclusions}

One year after treatment of patients with hypertension with concomitant thyrotoxicosis, double fixed combinations of antihypertensive drugs perindopril with indapamide and perindopril with amlodipine showed a statistically significant decrease in both ABPM $(p=0.01)$ and central blood pressure $(\mathrm{p}=0.0001)$.

The effectiveness of antihypertensive therapy in patients with hypertension with concomitant thyrotoxi- cosis depends on the compensation of the thyroid condition. Achieving euthyroidism contributed to an additional reduction in blood pressure on the background of antihypertensive therapy with bisoprolol and perindopril and provided a reduction not only indicators of the daily profile of SBP blood pressure (24 SBP $(\mathrm{p}<0.01)$, aSBPday $(\mathrm{p}<0.01)$, aSBPnight $(\mathrm{p}<0.01), \mathrm{HR}$, and the level of central blood pressure $(\mathrm{p}<0.01)$.

Achieving and maintaining the target blood pressure in patients with hypertension with concomitant thyrotoxicosis during the year of double combination antihypertensive therapy with perindopril with indapamide, perindopril with amlodipine, bisoprolol with perindopril did not provide reliable improving of the structural and functional state of the heart.

\section{Conflict of interest}

The authors declare that they have no conflicts of interest.

\section{References}

1. Basnet, S., Dhital, R., Tharu, B., Ghimire, S., Poudel, D. R. (2018). Association between thyroid abnormalities and hypertension among hospitalized US patients: data from the National Inpatient Sample. Cardiovascular Endocrinology \& Metabolism, 7 (4), 97-98. doi: http://doi.org/10.1097/xce.0000000000000155

2. Yildiz, C., Altay, M., Yildiz, S., Çağir, Y., Akkan, T., Ünsal, Y. A., Beyan, E. (2019). Arterial stiffness in hyperthyroid patients is deteriorated due to thyroid hormones. Archives of Endocrinology and Metabolism, 63 (3), 258-264. doi: http://doi.org/ 10.20945/2359-3997000000135

3. Amosova, K. M., Shyshkina, N. V., Rokyta, O. I., Rudenko, Yu. V., Katsytadze, I. Yu. (2016). Comparative evaluation of changes in brachial and central blood pressure in different categories of patients with uncomplicated arterial hypertension and determinants of pulse pressure amplification. Sertse i sudyny, 1, 37-45.

4. Berta, E., Lengyel, I., Halmi, S., Zrínyi, M., Erdei, A., Harangi, M. et. al. (2019). Hypertension in Thyroid Disorders. Frontiers in Endocrinology, 10. doi: http://doi.org/10.3389/fendo.2019.00482

5. Alekseeva, O. A., Shaposhnik, I. I., Bogdanov, D. V. (2019). Restoration of clinical and instrumental parameters of the cardiovascular system in patients with diffuse toxic goiter after resolution of thyrotoxicosis. Almanac of Clinical Medicine, 47 (2), 138-148. doi: http://doi.org/10.18786/2072-0505-2019-47-013

6. Kniazkova, I. I., Zhadan, A. V., Nesen, A. O. (2017). Arterialna ryhidnist yak chynnyk ryzyku i likuvalna mishen pry arterialnii hipertenzii. Praktychna anhiolohiia. 1 (76), 5-14.

7. Tsymbaliuk, I. L. (2016). Optymizatsiia likuvannia ta profilaktyky sertsevo-sudynnykh porushen u khvorykh na arterialnu hipertenziiu, poiednanu z tyreotoksykozom. Zaporizhzhia.

8. Williams, B., Mancia, G., Spiering, W., Agabiti Rosei, E., Azizi, M., Burnier, M. et. al. (2018). 2018 Practice guidelines for the management of arterial hypertension of the European Society of Cardiology and the European Society of Hypertension. Blood Pressure, 27 (6), 314-340. doi: http://doi.org/10.1080/08037051.2018.1527177

9. Ross, D. S., Burch, H. B., Cooper, D. S., Greenlee, M. C., Laurberg, P., Maia, A. L. et. al. (2016). 2016 American Thyroid Association Guidelines for Diagnosis and Management of Hyperthyroidism and Other Causes of Thyrotoxicosis. Thyroid, 26 (10), 1343-1421. doi: http://doi.org/10.1089/thy.2016.0229

10. Marwick, T. H., Gillebert, T. C., Aurigemma, G., Chirinos, J., Derumeaux, G. (2017). Recommendations on the use of echocardiography in adult hypertension: a report from the European Association of Cardiovascular Imaging (EACVI) and the American Society of Echocardiography (ASE). Systemic Hypertension, 14 (2), 6-28. doi: http://doi.org/10.26442/2075082x_14.2.6-28

11. Babenko, A. Yu. (2014). Cardiovascular disorders in thyrotoxicosis of various origins: optimization of treatment approaches. Mezhdunarodnii endokrinologicheskii zhurnal, 8 (64), 65-78.

12. Hegedus, L. (2018). Does therapy for thyroid dysfunction decrease mortality? Endocrine Abstracts. Barcelona. doi: http:// doi.org/10.1530/endoabs.56.p16

13. Lillevang-Johansen, M., Abrahamsen, B., Jørgensen, H. L., Brix, T. H., Hegedüs, L. (2019). Duration of Hyperthyroidism and Lack of Sufficient Treatment Are Associated with Increased Cardiovascular Risk. Thyroid, 29 (3), 332-340. doi: http:// doi.org/10.1089/thy.2018.0320 
14. Cherenko, M. S. (2016). The current opinion on management and treatment of hyperthyroidism and other forms of thyrotoxicosis: review of the latest Guidelines of American Thyroid Association (2016). Clinical Endocrinology and Endocrine Surgery, 4 (56), 87-94. doi: http://doi.org/10.24026/1818-1384.4(56).2016.87324

Received date 26.05.2020 Accepted date 19.06.2020

Published date 31.07.2020

Vira Tseluyko, MD, Professor, Head of Department, Renowned Leader of Science and Technics of Ukraine, Department of Cardiology and Functional Diagnostics, Kharkiv Medical Academy of Postgraduate Education, Amosova str., 53, Kharkiv, Ukraine, 61176

E-mail: viratseluyko@ukr.net

Daria Korchagina, Postgraduate Student, Department of Cardiology and Functional Diagnostics, Kharkiv Medical Academy of Postgraduate Education, Amosova str., 53, Kharkiv, Ukraine, 61176

E-mail: korchagina.daria@ukr.net

UDC 547.962.9: 61-08

DOI: $10.15587 / 2519-4798.2020 .209167$

\section{KERATITIS CAUSED BY PSEUDOMONAS AERUGINOSA: TREATMENT IN THE EXPERIMENT}

\section{N. Malachkova, N. Kryvetska, V. Kryvetskyi}

Метою дослідження було дослідити ефективність лікування викликаного Р. aеruginosa кератиту в експерименті з використанням офіцинальних офтальмологічних форм антибіотиків, ефективних проти збудника.

Матеріали та методи. Гнійний кератит викликали у 36 дорослих кроликів масою 3-3,5 кг иляхом нанесення клінічного штаму P. aеruginosa у вигляді суспензї одноденної культури мікроорганізму в концентрації $5 \times 108$ КУО/мл на частково деепітелізовану (на площуі приблизно 1 см²) рогівку з подальшим покриттям протягом 24 годин м'якою контактною лінзою з белафілкону $A$ (вміст води: $36 \%$, киснепроникність DK/t:110.0). У половині випадків мікробні біоплівки попередньо вирощували на поверхнях контактних лінз шляхом інкубації в бульйонній культурі штаму P. aeruginosa.

Лікування кератиту проводили за допомогою очних офіцинальних форм антибіотиків: левофлоксацину 0,5\%, ичипрофлоксацину 0,3\%, тобраміцину 0,3\%. Їх ефективність проти штаму Р. aеruginosa попередньо була доведена іп vitro. Тварин поділяли на три співставні за ступенем тяжкості групи кератитів, у кожній з яких лікування проводили одним із трьох зазначених антибіотиків. У половині випадків у межах кожної групи антибіотик поєднувався з офіцинальною очною формою декаметоксину 0,02\%. Антибіотики застосовували в режимі якнайчастішої інстиляиї перші 2 дні після початку гнійного кератиту, потім 5 i 4 рази на день.

Очінка процесу проводилась на онові клінічних ознак, культивування, офтальмологічного дослідження рогівки з використанням флюоресцеїнового тесту та фотофіксацією. Тварин виводили на 7, 10, 14 добу (залежно від строків епітелізації ураженої рогівки).

Результати. Всього було змодельовано 36 випадків гнійного кератиту, спричиненого Р. aeruginosa y кролів: 8 помірного (22,2 \%), 13 середньо-важкого (36,6\%), 15 - важкого (41,7\%).

Незалежно від обраного антибіотика, через 10-12 годин після видалення зараженої контактної лінзи та початку лікування зазвичай спостерігалося інтенсивне посилення запального процесу. Згодом запальні явища поступово згасали до повної епітеліалізащї рогівки, щзо відбувалась на 7-8 добу при помірному кератиті, 10-12 добу для важких та середньо-важких у I та III групі, та 12-14 добу (для важких та середньо-важких у II групі). Порівняно з I групою (0,5 \% левофлоксачин), зменшення запалення рогівки та епітелізація ураження у групі II (ципрофлоксацин 0,3%) затримувались на 1-2 дні. Застосування 0,3\% тобрамічину (III група) забезпечило найвищий контроль гнійного запалення протягом перших трьохчотирьох днів, однак далі спостерігалось уповільнення позитивної динаміки та затримка епітеліізаціі порівняно з групою I. Для всіх досліджуваних груп застосування комбінованої антибактеріальної терапії 3 декаметоксином супроводжувалося прискоренням регресї̈ гнійно-запальних уражень, особливо через зменшення кон'юнктивальної реакиї та гноєвиділення.

Як наслідок лікування, у більшості (69,5\%) випадків спостерігалось виникнення ділянок непрозорого помутніння рогівки різної величини. Більмо сформувалося більш ніж у третині випадків, у всіх - внаслідок 